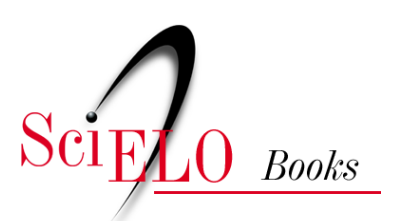

\title{
Representação discursiva da diversidade sexual em $O$ gato que gostava de cenoura, de Rubem Alves
}

\author{
Vanessa Rita de Jesus Cruz \\ Flávio Pereira Camargo
}

\section{SciELO Books / SciELO Livros / SciELO Libros}

CRUZ, VRJ., and CAMARGO, FP. Representação discursiva da diversidade sexual em $O$ gato que gostava de cenoura, de Rubem Alves. In: MITIDIERI, AL., and CAMARGO, FP., orgs. Literatura, homoerotismo e expressões homoculturais [online]. Ilhéus, BA: Editus, 2015, pp. 265-300. ISBN 97885-7455-442-6. Available from SciELO Books 〈http://books.scielo.org>.

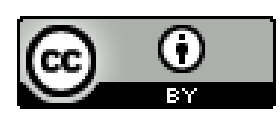

All the contents of this work, except where otherwise noted, is licensed under a Creative Commons Attribution $\underline{4.0 \text { International license. }}$

Todo o conteúdo deste trabalho, exceto quando houver ressalva, é publicado sob a licença Creative Commons Atribição 4.0.

Todo el contenido de esta obra, excepto donde se indique lo contrario, está bajo licencia de la licencia Creative Commons Reconocimento 4.0. 


\title{
REPRESENTAÇÃO DISCURSIVA DA DIVERSIDADE SEXUAL EM O GATO QUE GOSTAVA DE CENOURA, DE RUBEM ALVES
}

\author{
Vanessa Rita de Jesus Cruz $^{1}$ \\ Flávio Pereira Camargo ${ }^{2}$
}

\section{Curriculo, diversidade sexual e ensino de literatura infantil}

A escola e o professor constituem-se como mediadores da criança e do adolescente com o conhecimento e com o mundo que o cercam. Por isso, devemos estar atentos para as noções, os conceitos, as ideias e os valores que pregamos e perpetuamos como corretos. Conhecimento, poder e identidade social estão intimamente relacionados. Como não poderia ser diferente, em se tratando da educação, o currículo não fica aquém da produção do social. Conforme Tomaz Tadeu da Silva (2009), não apenas o currículo,

1 Mestre em Ensino de Língua e Literatura pela Universidade Federal do Tocantins/Campus de Araguaína. É professora efetiva de Língua Portuguesa e Literatura da rede estadual de ensino do Estado do Tocantins.

E-mail: 〈vanessalinguagens@hotmail.com〉

2 Pós-doutor em Estudos Literários pela UFMG. Doutor em Literatura pela UnB. Doutor e Mestre em Letras e Linguística (Estudos Literários) pela UFG. Atualmente, é professor de Literatura Brasileira da UFT/Campus Universitário de Araguaína, atuando na graduação e no Programa de Pós-Graduação em Letras. E-mail: 〈camargolitera@gmail.com〉. 
mas o próprio discurso sobre o currículo está implicado nos processos que regulam e governam a conduta humana. Ele - o discurso - constitui um dos elementos que ligam o saber e o poder, de que fala Foucault.

Ainda segundo Silva (2009), retomando Foucault, as modernas formas de governo precisam conhecer a população a ser governada, para melhor controlá-la. As estratégias de controle não são apenas externas; pretende-se também o autogoverno dos indivíduos, tendo em vista a democracia. Têm-se as estratégias para se conhecer os individuos, mas eles também precisam conhecer a si mesmos para se autogovernar.

A área do currículo representa uma das formas de conhecimento dos individuos, implicadas em estratégias de poder:

A Teoria do Currículo consiste precisamente nisso: em formular formas de melhor organizar experiências de conhecimento dirigidas à produção de formas particulares de subjetividade: seja o sujeito conformista e essencializado das pedagogias tradicionais, seja o sujeito 'emancipado' e 'libertado' das pedagogias progressistas. A Teoria do Currículo é uma espécie muito especial de tecnologia de governo, na medida em que seu saber específico não lida apenas com um conhecimento sobre o indivíduo (como a Psicologia, por exemplo), mas com um conhecimento sobre os nexos entre conhecimento e indivíduo (SILVA, 2009, p. 192 - grifos do autor). 
Dessa maneira, a Teoria do Currículo, a partir do objetivo de produzir uma subjetividade determinada, tenta identificar quais conhecimentos, atitudes e valores são necessários e adequados para obter essa subjetividade. O currículo pretende produzir sujeitos particulares; a Teoria do Currículo, por sua vez, busca a melhor maneira de produzi-los (SILVA, 2009). Vemos que o que está em jogo é a produção de identidades legítimas e inteligíveis. A Teoria do Currículo, que deveria prestar-se a criticar os currículos existentes, zelar pela emancipação e libertação, está relacionada com as estratégias de poder que pretendem regular e governar os sujeitos.

Não podemos negar o caráter histórico e político do currículo: variadas atividades podem ser feitas por meio dele, considerando-se a época e o contexto. Mas ele possui também um caráter social, haja vista que se produz conhecimento na relação entre as pessoas. Aqui, abrimos espaço para pontuar a ressalva que faz Silva (2009, p. 194) ao afirmar que "é importante ver o currículo não apenas como sendo constituído de 'fazer coisas' mas também vê-lo como 'fazendo coisas às pessoas"' (grifos...). Ora, o currículo não deve ser visto apenas como ações - aquilo que fazemos com os materiais recebidos -, mas há de se considerar também os seus efeitos - aquilo que ele nos faz. Esses dois sentidos estão permeados de relações de poder. Mesmo considerando essas relações, se agimos sobre o currículo, podemos desviar, subverter e contestar esses 
materiais, porém, como já dissemos, não apenas produzimos o currículo, também somos produzidos de formas específicas por relações de poder. O currículo constitui sujeitos particulares e demarca o seu posicionamento nas divisões sociais.

O que vem descrito no currículo, de forma explícita ou implicita, expressa, de forma particular, noções sobre conhecimento, sobre a organização da sociedade e seus diferentes grupos. As narrativas ali contidas

[...] dizem qual conhecimento é legítimo e qual é ilegitimo, quais formas de conhecer são válidas e quais não o são, o que é certo e o que é errado, o que é moral e o que é imoral, o que é bom e o que é mal, o que é belo e o que é feio, quais vozes são autorizadas e quais não o são. As narrativas contidas no currículo trazem embutidas noções sobre quais grupos sociais podem representar a si e aos outros e quais grupos sociais podem apenas ser representados ou até mesmo serem totalmente excluídos de qualquer representação. Elas, além disso, representam os diferentes grupos sociais de forma diferente: enquanto as formas de vida e a cultura de alguns grupos são valorizadas e instituídas como cânon, as de outros são desvalorizadas e proscritas (SILVA, 2009, p. 195).

A partir dessa citação, podemos perceber como as narrativas do currículo fixam noções específicas sobre classe, etnia, gênero 
e sexualidade e como seus discursos podem autorizar ou desautorizar, legitimar ou deslegitimar, incluir ou excluir. Logo, o currículo é, de certa forma, o responsável por quem nos transformamos. Se, por um lado, para governar, dispor de poder, é preciso conhecer; por outro lado, o saber não está livre dos efeitos do poder. O currículo, como conjunto de saberes, está ligado ao poder. Este é que seleciona, inclui, exclui, produz e reforça os conhecimentos, os grupos sociais e os modelos válidos. O que podem, então, a escola e o professor fazer diante dessas relações de poder e divisão, que supervaloriza algumas identidades e conhecimentos e subjuga os "outros"?

Dentre as identidades que vivem subjugadas pelas relações de poder estão a sexual e a de gênero. Segundo Foucault (1988), é comum dizer que a época clássica submeteu o sexo das crianças à ocultação. O autor ressalta que se continuou a falar do sexo, porém de outras formas, por outras pessoas, com outros pontos de vistas, com a intenção de se obter outros efeitos. Por isso, devemos estar atentos ao não dito, à forma como eram divididos os que estavam autorizados a dizer e os que não podiam falar e o que podiam falar, que grau de discrição era exigido de uns e de outros. Os muitos silêncios permeavam e apoiavam os discursos.

Para Foucault (1988), os colégios do século XVIII, por meio de seus dispositivos arquitetônicos, os regulamentos das disciplinas e a organização interior, falavam de sexo continuamente: 
Os organizadores levaram-no (o sexo) em conta de modo permanente. Todos os detentores de uma parcela de autoridade se colocam num estado de alerta perpétuo: reafirmando sem trégua pelas disposições, pelas precauções tomadas, e pelo jogo das punições e responsabilidades. O espaço da sala, a forma das mesas, o arranjo dos pátios de recreio, a distribuição dos dormitórios (com ou sem separações, com ou sem cortina), os regulamentos elaborados para a vigilância do recolhimento e do sono, tudo fala da maneira mais prolixa da sexualidade das crianças (p. 34).

O discurso institucional constatava a sexualidade, precoce, ativa e permanente. A sexualidade do colegial, ao longo do século XVIII, torna-se um problema público: médicos aconselham diretores e professores das instituições, assim como as famílias; os pedagogos realizam projetos e os professores se dirigem aos seus alunos com recomendações e para os mesmos escrevem livros contendo conselhos médicos e exemplos que edificam.

Por tudo isso, Foucault (1988) nos diz que a instituição pedagógica não impôs um silêncio ao sexo das crianças e dos adolescentes. Desde o século XVIII, os seus discursos tratam desse tema. Nesse mesmo século e no seguinte, entram em cena outros focos que também produzirão os discursos sobre o sexo: a medicina, a psiquiatria e a justiça penal. A partir daí, ao longo dos tempos, os controles sociais filtram a sexualidade da so- 
ciedade: casais, pais, filhos, crianças e adolescentes, protegendo, separando e prevenindo, "solicitando diagnósticos, acumulando relatórios, organizando terapêuticas" (p. 37).

Os diferentes discursos eram produzidos onde residia o poder e eram um meio para o seu exercício. Em toda parte, incita-se o falar sobre o sexo, mas também se criam os dispositivos para que se ouça e se registre, para que se observe, interrogue e formule. Ele ganha existência discursiva. Discursos proferidos por diferentes instituições ganham forma, segundo Foucault (1988), na demografia, na biologia, na medicina, na psiquiatria, na psicologia, na moral e na crítica politica. Os três últimos séculos caracterizam-se pela variedade de meios criados para que dele se pudesse falar, para que ele falasse, para que se pudesse escutar, registrar e redistribuir aquilo que se dizia sobre o sexo.

Havia, até o final do século XVIII, três códigos explícitos que regiam as práticas sexuais: o direito canônico, a pastoral cristã e a lei civil. Eles determinavam o lícito e o ilícito. Estavam voltados para as relações matrimoniais, que eram permeadas de regras e de recomendações, portanto, ir contra as leis do casamento ou ater-se a prazeres estranhos era motivo de condenação. Os tribunais condenavam a homoafetividade, a infidelidade, o casamento sem a permissão dos pais e a bestialidade. A lei civil e a ordem religiosa cuidavam dos "contra-anatureza" e "contra-a-lei", de modo que não se podia infringir a ordem das coisas e dos seres. 
Considerando essa "aliança legítima", os discursos dos séculos XVIII e XIX provocaram duas modificações. A primeira diz respeito à monogamia heterossexual. Não se fala dela mais com tanta frequência, embora continue sendo a regra interna das práticas e dos prazeres. $\mathrm{O}$ casal legítimo passa a ter direito à discrição. A segunda modificação é que se passa a interrogar a sexualidade das crianças, dos loucos e dos criminosos; "é o prazer dos que não amam o outro sexo, os devaneios, as obsessões, as pequenas manias ou as grandes raivas" (FOUCAULT, 1988, p. 46). Essas sexualidades não serão menos condenadas. A lei da aliança e a ordem dos desejos serviram, no Ocidente, como sistemas de regras que regeram o sexo. Não se podia infringir a legislação e a moral do casamento nem causar danos à regularidade do funcionamento natural, sob pena de sanção.

Mas eis que começa a surgir uma "gentalha diferente", apesar de possuirem parentescos com os antigos libertinos:

Do final do século XVIII até o nosso, eles correm através dos interstícios da sociedade perseguidos pelas leis, mas nem sempre, encerrados freqüentemente nas prisões, talvez doentes, mas vitimas escandalosas e perigosas presas de um estranho mal que traz também o nome de "vício" e, às vezes de "delito". Crianças demasiado espertas, meninas precoces, colegiais ambíguos, serviçais e educadores duvidosos, maridos cruéis ou maníacos, colecionadores solitários, transeuntes 
com estranhos impulsos: eles povoam os conselhos de disciplina, as casas de correção, as colônias penitenciárias, os tribunais e asilos; levam aos médicos suas infâmias e aos juizes suas doenças. Incontável família dos perversos que se avizinha dos delinquentes e se aparenta com os loucos. No decorrer do século eles carregavam sucessivamente o estigma da 'loucura moral', da 'neurose genital', da 'aberração do sentido genésico', da 'degenerescência' ou do 'desequilibrio psíquico' (FOUCAULT, 1988, p. 47, grifos do autor).

Essas sexualidades periféricas serão alvo de diversas instâncias de controle e de diferentes mecanismos de vigilância. Hoje, essas identidades ainda são marcadas pelo crivo da inferioridade e, de diversos lugares, ressoam as vozes que querem marcá-las como imorais e ilícitas. Mesmo com as falas que, dia após dia, enfatizam a pluralidade, a nossa sociedade ainda não se desvencilhou de certos discursos tidos como naturais, dentre eles o da heteronormatividade compulsória. Graças a ela, a identidade homoafetiva ainda não pode ser vivida sem receios.

Acreditamos na literatura como uma possibilidade de encontro com outras identidades, como um caminho capaz de romper com estereótipos e proporcionar o respeito àqueles que possuem hábitos, práticas e desejos diferentes. Assim, o texto que passamos a analisar - e que se constitui como uma sugestão de narrativa a ser incluída no currículo escolar - pode proporcionar ao leitor um encontro com a diversidade. 


\section{Análise da narrativa $O$ gato que gostava de cenoura, de Rubem Alves}

O gato que gostava de cenoura, de Rubem Alves, inicia-se com uma estrutura arquetipica dos contos de fadas tradicionais: "Era uma vez um gatinho" (ALVES, 2009, p. 5). Essa introdução apresenta a personagem principal da narrativa: um gato. Trata-se de uma fábula, com espaço e tempo indeterminados, em que o hábito alimentar é responsável por marcar o binarismo normal x anormal, para se referir à diferença que é constitutiva da identidade de Gulliver. Diferença que, aos poucos, vai revelando ao leitor que a identidade daquele gato destoa daquela idealizada pelos pais. Em páginas posteriores, essa diferença é apresentada ao leitor como parte da identidade homoafetiva de Gulliver ${ }^{3}$.

Logo no início da história, temos a caracterização da espécie animal gato e percebemos a identidade sendo marcada através de determinadas representações sociais:

Gatos são animais nobres.

Felinos.

Primos dos tigres, dos leões, das onças. Velozes, silenciosos, macios, elegantes. Símbolo da magia - toda bruxa tem um gato, preferivelmente negro.

Símbolo daquilo que fascina e atrai. Um homem bonito, amado pelas mulheres,

3 A antítese normal x anormal, que vai se construindo no decorrer da narrativa, resulta na oposição entre heterossexualidade $x$ homoafetividade ao final da narrativa. 
é um 'gato'. Uma mulher bonita, amada pelos homens, é uma 'gata'.

Os gatos, como todos os felinos, são caçadores (ALVES, 2009, p. 5, grifos do autor).

O nosso personagem principal pertence a uma familia nobre, temida, e deveria ser um selvagem, considerando o grupo dos felinos ao qual ele pertence, mas, ao contrário do que se espera, ele é meigo, é diferente daquilo que é apresentado como característica identitária de seu grupo familiar. Há, aqui, uma oposição de identidades: gato x outro e a construção da alteridade: eu x outro. Essa classificação mostra "como as relações sociais são organizadas e divididas" (WOODWARD, 2000, p. 14), pois o sistema classificatório "aplica um princípio de diferença a uma população de uma forma tal que seja capaz de dividi-la (e a todas as suas características) em ao menos dois grupos opostos - nós/eles" (WOODWARD, 2000, p. 40).

Segundo Kathryn Woodward (2000), as identidades ganham sentido por meio da linguagem e também pelos sistemas simbólicos que as representam. A representação, simbolicamente, classifica o mundo, as pessoas e as relações. Para a autora (2000, p. 10), a construção da identidade "é tanto simbólica quanto social". Ambos os processos - o social e o simbólico - são necessários para a construção das identidades. Por meio deles, define-se quem é excluído e quem é incluído. Um grupo é socialmente excluído quando é marcado, simbolicamente, como inimigo ou como um tabu. Isso 
implica em perdas materiais e sociais, podendo gerar a violência física e/ou verbal, além dos efeitos emocionais ou sentimentais.

A identidade homoafetiva, por exemplo, é excluída, considerada menor em relação à heterossexual. Os homoafetivos nem sempre usufruem os mesmos direitos que os heterossexuais, muitas vezes não podem ocupar os mesmos espaços e os mesmos cargos profissionais. Percebemos que a identidade do que é ser gato é construída apenas com atributos positivos e superiores. O gato possui grau de parentesco com animais temidos pelos demais - os tigres, os leões e as onças -, que têm autoridade sobre aqueles considerados inferiores e, culturalmente, a nossa sociedade o utiliza para elogiar o homem e a mulher. Neste último aspecto, vale ressaltar que o homem chamado de gato é aquele bonito, "amado pelas mulheres" e a mulher denominada de gata é aquela que, além de bonita, é "amada pelos homens". Em ambos os casos, o amor e a atração sexual se dão pelo oposto, em uma relação heterossexual, não se evidenciando a possibilidade de o homem e a mulher serem "gatos" em uma relação homoafetiva.

Na citação anterior, vemos que é "natural" que os gatos sejam caçadores. É da natureza do grupo, de sua raça possuir essa identidade. Esta é marcada como natural, como se não estivesse sempre em processo de construção, em devir. A identidade é vista em uma perspectiva 
essencialista $^{4}$, fixa e imutável, biologicamente determinada. A identidade sexual, por exemplo, parece reivindicar uma base biológica para se afirmar. Não se considera a fluidez das identidades e o fato de que elas não estão presas às diferenças imutáveis que valem em todos os contextos e épocas.

Na narrativa, o hábito alimentar assinala a identidade de um grupo e serve como marcação da diferença:

Gatos caçam peixes, ratos e pássaros. Um peixinho bobo, na superficie do tanque,

um passarinho distraído, comendo quirera,

um ratinho molenga, passeando pela casa,

e era uma vez um peixinho, um passarinho e um ratinho... Viraram comida de um gato.

Assim são os gatos, caçadores carní$\operatorname{voros}^{5}$ (ALVES, 2009, p. 5).

4 Segundo Kathryn woodward (2000), há duas versões do essencialismo identitário. A primeira é aquela em que a identidade é mostrada como produto da história, ela é fundamentada na "verdade" da tradição. A segunda é aquela que apresenta a identidade como "natural" e fixa e tem a "verdade" enraizada na biologia.

5 Os verbos "caçar" e "comer" merecem, aqui, um parêntese, tendo em vista o caráter metafórico do texto. Esses verbos remetem à cadeia alimentar, ao hábito de comer o outro, movimento antropofágico entre os animais carnívoros que caçam para sobreviver, em que estão em jogo a força e o instinto animal. Elementos que são, inclusive, metafóricos entre os humanos, uma vez que esses verbos, antropologicamente, remetem ao hábito alimentar - podem também denotar a virilidade masculina - e, ao mesmo tempo, às práticas sexuais. Caçar, no meio GLS (Gays, Lésbicas e Simpatizantes), é uma gíria para quem está a procura do outro, de um parceiro, seja para namorar ou, simplesmente, satisfazer o desejo sexual. 
Percebemos, pela citação, as microrrelações de poder existentes em uma comunidade. É um poder que se instaura de cima para baixo. Um grupo tem o domínio sobre os outros, tornando-os submissos e sem o direito de se manifestar. Esses outros são sempre colocados em uma posição de inferioridade. Os adjetivos utilizados para qualificar as outras espécies indicam um grau menor de importância e, de certa forma, submissão. Certas identidades sucumbem diante daquelas consideradas superiores e dominadoras.

As identidades diferentes, que não correspondem ao modelo, que fogem às expectativas e às normas sociais, como pontua Woodward (2000), são vistas como "estranhas" ou "desviantes":

Eles - os gatos - desprezam os coelhos - animais do mesmo tamanho, só que nem são caçadores nem carnívoros. Coelhos comem cenouras. Os gatos odeiam cenouras. Para os gatos, quem come cenoura é ruim da cabeça. Os coelhos devem ser doidos... (ALVES, 2009, p. 5).

Ou seja, os coelhos - os diferentes - precisam ser tratados, curados, é o discurso médico do século XVIII, de que nos fala Foucault. Ser diferente, ter gostos diferentes é sinal de loucura, de anormalidade, e não se encaixar em modelos padronizados é ser alvo de atenção e cuidados. Vemos que há a representação positiva de uma identidade - ser gato - e uma 
representação negativa de outra identidade ser coelho:

A representação, compreendida como um processo cultural, estabelece identidades individuais e coletivas [...]. Os discursos e os sistemas de representação constroem os lugares a partir dos quais os indivíduos podem se posicionar e a partir dos quais podem falar (WOODWARD, 2000, p. 17).

Alguns grupos têm direito à fala e se autorrepresentam, outros são apenas representados, são objeto do discurso alheio e têm as suas identidades construídas nos discursos daqueles que podem dizê-lo. As representações heterossexuais e a violência que produzem subjugam a subjetividade homoafetiva. Os termos, as expressões e as piadas não representam apenas uma injúria, trata-se da construção de uma imagem social, delimitada pela sexualidade e pela estigmatização da homoafetividade.

A identidade, que é marcada pela diferença - algumas diferenças, geralmente, são consideradas mais importantes que outras, principalmente em alguns contextos e lugares -, é também relacional. Para existir, uma identidade depende de algo fora dela, de outra identidade, aquela que ela não é, mas que oferece as condições para a sua existência. Logo, a diferença é marcada pela exclusão. Se for gato, não pode ser coelho, prevalecendo sempre a relação de antítese. O hábito alimentar, o parentesco com 
outros animais, o fato de ser caçador e carnivoro, simbolicamente, relaciona a identidade do ser gato com as outras identidades. Para que a identidade heterossexual exista e os membros do grupo se reconheçam como tal, é necessário que a identidade homoafetiva esteja ali.

As oposições binárias, conforme Woodward (2000), são a maneira mais extrema de marcar a diferença e são essenciais para que se compreenda o processo de construção cultural das identidades. Seus termos costumam expressar oposições cristalizadas, estando um dos termos sempre em relação de superioridade; essas oposições são ligadas às relações de poder. Ao contrário dos outros gatos, Gulliver não gostava de caçar, nem comer peixes, ratos e pássaros. Ele era diferente. Gulliver contraria, portanto, as expectativas de seus pais, que lhe deram esse nome - "o nome de um gigante" (ALVES, 2009, p. 6) - por acreditarem que o filho seria um "gato enorme, forte, valente, caçador" (ALVES, 2009, p. 6), o que seria "normal" para a espécie dele.

Por meio desse nome - a linguagem nomeia e classifica -, percebemos a idealização dos pais em relação à identidade do filho. Gulliver contraria o "normal", o preestabelecido, sendo considerado pela sociedade e por seus pares um corpo que não pesa, não tem valor, pois transgride a norma, incomoda. Há uma desconstrução da identidade idealizada por seus pais e pela sua comunidade em relação ao que é ser gato, uma vez que Gulliver não atende àquilo que se espera de 
sua espécie: "Seus pais lhe traziam deliciosos ratinhos recém-nascidos, pardais saborosos, peixes cheirosos: tudo em vão. Ele quase vomitava" (ALVES, 2009, p. 6). De uma maneira ou de outra, há a tentativa e a insistência das instituições em modificar e moldar as identidades daqueles que fogem ao padrão instituido socialmente.

O comportamento estranho dos sujeitos está sempre sob o alvo dos olhares que o descobrem, o percebem, o investigam, fazendo com que ele seja confessado e disciplinado. Conforme Foucault (1988), a partir do século XVIII, os discursos sobre o sexo se aceleraram no campo de exercício do poder. Há uma incitação a falar de sexo cada vez mais. Com a evolução da pastoral católica e do sacramento da confissão, após o Concílio de Trento, o sexo

[...] não deve mais ser mencionado sem prudência; mas seus aspectos, suas correlações, seus efeitos devem ser seguidos até às mais finas ramificações: uma sombra num devaneio, uma imagem expulsa com demasiada lentidão, uma cumplicidade mal afastada entre a mecânica do corpo e a complacência do espírito: tudo deve ser dito [...] o sexo é açambarcado e como que encurralado por um discurso que pretende não lhe permitir obscuridade nem sossego (FOUCAULT, 1988, p. 25-26).

Todos os comportamentos e atitudes "estranhas" devem ser considerados. Os pais de 
Gulliver, então, resolvem levá-lo ao médico. A diferença é vista como uma patologia. A confissão também era necessária para as intervenções médicas, para a elaboração do diagnóstico eficaz na busca pela cura. Os médicos não possuíam uma explicação para a falta de apetite do gatinho, pediam exames, mas descobriam que não havia nada de errado com o corpo de Gulliver.

Os pais dele nem imaginavam que ele comia escondido a "comida proibida", pois ele comia cenoura, como os coelhos. O que é proibido só pode ser feito às escondidas, por isso Gulliver não contava a ninguém o que comia. A proibição também serve para distinguir as identidades que são inclusas em um sistema ou grupo daquelas que são excluídas. Se alguém descobrisse do que Gulliver se alimentava, "Todos ririam dele, um gato que tem o gosto dos coelhos..." (ALVES, 2009, p. 8), ele não poderia assumir a sua identidade, caso contrário, seria ridicularizado.

Por conta desse seu gosto diferente, Gulliver estava sempre sozinho, não saía com os outros gatos, pois os outros saíam para caçar e comer ratos e Gulliver, quando tentava fazer o mesmo, acabava vomitando. Ele tenta dissimular a sua identidade. O diferente, por medo da repressão, da violência e da rejeição, até tenta seguir o modelo padrão, ajustar-se às regras culturais e sociais. Gulliver "Preferia a solidão. Ninguém o entenderia" (ALVES, 2009 , p. 8). Ele não tinha amigos porque era diferente, e não ter amigos fazia parte de sua 
identidade estigmatizada social e culturalmente pelo outro.

O medo da não aceitação, da gozação, da injúria e da agressão, constrói a identidade e a personalidade daqueles que são considerados diferentes. Gulliver não vivia sozinho porque gostava, mas porque precisava. A identidade que o moldava era determinada pela posição que ele ocupava. O medo de ser descoberto fazia com que Gulliver se mantivesse afastado dos outros gatos. Como pontua Didier Eribon (2008), as subjetividades "homossexuais" também são construídas a partir da procura dos meios de fuga da injúria e da violência, por isso eles desenvolvem diferentes tipos de comportamento para serem utilizados de acordo com as pessoas com quem convivem e os ambientes que frequentam.

A mãe gato, preocupada com o filho, afirma que tem "medo de que [ele] esteja fazendo alguma coisa errada" (ALVES, 2009, p. 8). A família também é uma instituição vigilante, que pretende disciplinarizar os corpos, os hábitos e os desejos, por isso, a mãe sugere que o pai siga Gulliver e assim ele faz. Não ser igual aos de sua espécie faz com que a mãe de Gulliver o imagine fazendo "coisa errada". O considerado "correto" é aquilo que seu grupo tem o hábito de fazer, comer e realizar.

Gulliver, chegando ao sítio de seu Joaquim, onde havia canteiros com diversos tipos de hortaliças, dentre os quais canteiros de cenoura, se certifica de que está sozinho, olha para um lado e para o outro e começa a 
"fazer a coisa proibida, horrivel, desprezivel para um gato. Começou a comer cenouras" (ALVES, 2009, p. 8). O gato se certifica de que ninguém estava vendo seu ato "pecaminoso" e só aí assume sua identidade. Ali, no meio das hortaliças, Gulliver pode ser ele mesmo, sem fingimentos, pois o "armário" também é "um espaço de liberdade e um meio - o único - de resistir e de não se submeter às injunções normativas" (ERIBON, 2008, p. 67).

Esses canteiros não deixam de, metaforicamente, representar as diversas possibilidades de relações afetivas e sexuais. Não há uma única maneira de se viver - afetiva e sexualmente -, embora a heteronormatividade compulsória assim faça parecer. São diversas as identidades e muitas ainda têm que viver à margem, na fronteira do lícito e do ilícito, ou se manifestar somente à noite, quando os sujeitos de "moral e bons costumes" estão em casa dormindo.

Esse acontecimento presenciado pelo pai provoca nele uma grande decepção, pois desejava um filho que se parecesse com um tigre. Ao voltar para casa, o pai e a sua mulher, a mãe gata, "choraram amargamente" (ALVES, 2009, p. 8). Por não materializar a norma, Gulliver é motivo de tristeza para os pais. Como ele, muitos sujeitos, quando resolvem assumir a sua identidade homoafetiva, são vistos como motivo de sofrimento e vergonha para a família, às vezes são expulsos de casa e rejeitados pelos familiares. Foi o que aconteceu, e se complicou, quando um colega de escola também o viu 
comendo cenoura. "Gulliver tornou-se objeto de zombaria" (ALVES, 2009, p. 10) e os amigos começaram a chamá-lo de coelho.

$\mathrm{O}$ ato de linguagem, atravessado constantemente pelas relações sociais, nomeia a diferença; é por meio dela e através dela que ocorre a "dominação simbólica" (ERIBON, 2008, p. 95), ou seja, a definição das percepções que se tem do mundo e das representações socialmente legítimas. A injúria e o insulto fazem o outro, o diferente, o homoafetivo, ser apontado e ridicularizado, pois a linguagem o nomeia como estranho, como objeto e como abjeto, a partir do olhar do outro:

Descubro que sou alguém de quem se pode dizer isto ou aquilo, alguém que é objeto dos olhares, dos discursos e que é estigmatizado por esses olhares e esses discursos. A 'nomeação' produz uma conscientização de si mesmo como um 'outro' que os outros transformam em 'objeto' (ERIBON, 2008, p. 28).

A injúria produz o efeito da vergonha, do menosprezo e da solidão, institui e perpetua o corte entre os "normais" e os "estigmatizados" e esse corte se enraíza nos sujeitos. A agressão verbal representa uma ameaça constante à vida social daqueles que não têm a sua identidade aceita: "Para o homossexual 'descoberto', a injúria não seria mais apenas um horizonte, uma potencialidade cuja ameaça está sempre presente no espírito, mas um inferno no cotidiano" (ERIBON, 2008, p. 67). O homoafetivo vive em 
um mundo de injúrias que preexistem àquele que as proferem e àqueles que as recebem.

Por ser a linguagem histórica, política e social, é necessária uma análise das estruturas antropológicas que constituem a nossa sociedade a fim de se compreender como a injúria constitui a identidade homoafetiva e de que forma pode ser combatida. Não teríamos resolvido o problema do preconceito e da discriminação, tendo em vista que, como pontua Eribon (2008, p. 101), a injúria representa apenas a ponta, o "traço verbal limite da violência simbólica", que designa a sexualidade segundo hierarquizações e exclusões que sempre colocam a homoafetividade em um grau de inferioridade. Aqueles que não possuem os mesmos hábitos não são aceitos e ficam à margem.

A injúria acaba por determinar a relação daquele que a recebe com o mundo, produzindo no sujeito um sentimento de insegurança, de angústia - e nas crianças e adolescentes, produz até o pânico. Vivem a angústia constante de serem descobertos, por isso, alguns sujeitos tentam viver na norma para fugir do controle e da vigilância. As instituições sociais têm contribuido para que a dissimulação da identidade homoafetiva não tenha fim, uma vez que aprovam tal prática, contribuindo para perpetuá-la, em vez de se posicionarem contra a ordem social que determina a heterossexualidade compulsória e estigmatiza outras identidades.

No texto analisado, os pais de Gulliver, sofrendo junto com o filho, aprenderam, com livros de psicologia, que o medo do sofrimento 
constitui-se como uma ferramenta para que os bichos mudem seus hábitos: "Até bichos ferozes como leões e ursos, por medo, aprenderam a dançar nos circos" (ALVES, 2009, p. 10). Eles esperam que, com o sofrimento, o protagonista mude os seus hábitos, discipline seu corpo, seus desejos e suas práticas. Ele não é aceito pelo sistema, pela instituição familiar e pelos amigos justamente porque é diferente. Então, os pais dele mandam-no conversar com o gato-padre, D. João Severo, cujo nome sugere severidade, nomeia a sua identidade e função.

Segundo Foucault (1988), a nossa civilização é a única a praticar uma scientia sexualis. A sociedade desenvolveu procedimentos que se ordenam em uma forma de poder-saber para se dizer a verdade do sexo. A confissão é um dispositivo da ciência do sexo e, desde a Idade Média, constitui-se como um dos rituais mais importantes como produção de verdade nas sociedades ocidentais, tais como:

[...] a regulamentação do sacramento da penitência pelo Concílio de Latrão em 1215; o desenvolvimento das técnicas de confissão que vêm em seguida; o recuo, na justiça criminal, dos processos acusatórios; o desenvolvimento das provações de culpa (juramentos, duelos, julgamentos de Deus); e o desenvolvimento dos métodos de interrogatório e de inquérito; a importância cada vez maior ganha pela administração real na inculpação das infrações - e isso às expensas 
dos processos de transação privada a instauração dos tribunais de Inquisição, tudo isso contribui para dar à confissão um papel central na ordem dos poderes civis e religiosos (FOUCAULT, 1988, p. 67).

Somos uma sociedade que confessa. A confissão, pouco a pouco, desde o século XVI, deixou de ser um ritual exclusivo da prática da penitência. Todas as instâncias e relações passam a se utilizar da confissão (ajustou-se a técnica da confissão ao discurso científico): a justiça, a medicina, a pedagogia, as relações familiares e amorosas, no cotidiano ou nas situações solenes. Entre delinquentes e peritos, doentes e médicos, alunos e pedagogos, crianças e pais. Os crimes, os pecados, os desejos, os pensamentos, os sonhos, tudo deve ser confessado, em particular ou em público, aos pais, aos educadores, aos médicos, a quem se ama ou a si mesmo, o prazer e/ou a dor, que não se pode confiar ao outro. "Quando a confissão não é espontânea ou imposta por algum imperativo interior, é extorquida; desencavam-na na alma ou arrancam-na ao corpo" (FOUCAULT, 1988 , p. 68), sendo aquele que a escuta dono não somente do perdão ou da condenação, mas também o dono da verdade. Portanto, além de exigir a confissão e decidir o que fazer após a mesma ser feita, o ouvinte deve elaborar um discurso de verdade sobre o que ouviu.

Por ser imposta por diferentes pontos, a confissão incorporou-se a nós, e o sujeito já não a percebe como estratégia de um poder 
que constrange. A verdade não é livre por natureza, a sua produção está ligada às relações de poder. A identidade do indivíduo foi ora autenticada pela relação que se estabelecia com o outro - a família, por exemplo - ora pelo discurso de verdade que o indivíduo era capaz de dizer sobre si mesmo. O sexo ainda é tema privilegiado na confissão, e por meio dela, verdade e sexo ligam-se:

O exame médico, a investigação psiquiátrica, o relatório pedagógico e os controles familiares podem, muito bem, ter como objetivo global aparente dizer não a todas as sexualidades errantes ou improdutivas mas, na realidade, funcionam como mecanismos de dupla incitação: prazer e poder. Prazer em exercer um poder que questiona, fiscaliza, espreita, espia, investiga, apalpa, revela; e, por outro lado, prazer que se abrasa por ter que escapar a esse poder, fugir-lhe, enganá-lo ou travesti-lo. Poder que se deixa invadir pelo prazer que persegue e, diante dele, poder que se afirma no prazer de mostrar-se, de escandalizar ou de resistir. Captação e sedução; confronto e reforço reciprocos: pais e filhos, adulto e adolescente, educador e alunos, médico e doente, e o psiquiatra com sua histérica e seus perversos, não cessaram de desempenhar esse papel desde o século XIX (FOUCAULT, 1988, p. 52-53).

Dessa maneira, a relação entre o poder, o saber e o prazer estão intimamente relacionados na narrativa. Por exemplo, o poder representado pelas instituições familiar, religiosa e 
médica, pelos colegas da escola; um saber que se dá quando os pais de Gulliver e os colegas da escola descobrem o seu gosto por cenouras e quando ele tem que confessar ao médico, ao padre e ao psicanalista o seu hábito alimentar diferente; e um prazer por parte de Gulliver, quando tenta escapar da vigilância ou quando pode assumir a sua identidade.

O discurso religioso funciona como repressão à atitude de Gulliver. Ele tem de confessar ao padre os seus pecados. O sujeito deve confessar as atitudes contrárias à lei e transformar todo o seu desejo em discurso. Um dos efeitos que pretendia a pastoral cristã era a "reconversão espiritual", o retorno a Deus, "efeito físico de dores bem-aventuradas por sentir no seu corpo as ferroadas da tentação e o amor que lhe resiste" (FOUCAULT, 1988, p. 29).

O gato-padre, com um pelo lustroso e pretíssimo, com olhos verdes e longo rabo encurvado - a descrição do padre exala poder e autoridade - abriu um livro sagrado e

[...] disse que Deus, o Gato Supremo, determinara que rato, passarinho e peixe são os manjares dos deuses. Assim, por determinação do Deus-Gato, gatos têm de comer ratos, passarinhos e peixes. Comer cenouras é pecado mortal. É contra a natureza. Ai lhe falou sobre o inferno, um lugar terrivel para onde vão todos os gatos que comem cenouras (ALVES, 2009, p. 10). 
O gato-padre disse que o inferno seria o destino de Gulliver se ele não parasse de comer cenouras e, como penitência, ordenou que comesse dois ratos. Ele tentou, pois era obediente, mas acabou vomitando. Observamos a penitência que lhe é dada, para fazer aquilo que era considerado "correto" e desistir de realizar os seus desejos. O discurso religioso inculca nos sujeitos que a homoafetividade é pecado, que a "multiplicação" - ordenada por Deus - sofre a ameaça de práticas não heterossexuais.

Deve-se se dizer a si mesmo e a outrem sobre os prazeres, sensações e pensamentos que envolvam o sexo. Colocá-lo em discurso não é simplesmente condená-lo ou tolerá-lo, mas inseri-lo em "sistemas de utilidade", regulando-o para o bem de todos, fazendo com que funcione "segundo um padrão ótimo" (FOUCAULT, 1988, p. 31). O discurso estabelecido diz que o que Gulliver faz é pecado e o certo seria ter outra postura, mais natural, "correta", comer rato, passarinho e peixe. Não mudar a sua postura e seus hábitos poderia fazer de Gulliver um merecedor do inferno.

Assim, na narrativa analisada, estão presentes o dispositivo da vigilância (instituição familiar), a técnica da confissão (feita ao médico, ao padre e ao psicanalista), a imposição de discursos e a correção (realizados pelo padre). Como nos diz Foucault (1988), o ritual da confissão envolve um discurso em que o sujeito que confessa corresponde ao sujeito do enunciado, desencadeando uma relação de poder, uma vez 
que, para se confessar, exige-se a presença mesmo virtual - de um parceiro, que é mais do que interlocutor. Este se constitui como a instância que solicita, impõe e avalia a confissão, intervindo com o julgamento, a punição, o perdão, o consolo e/ou a reconciliação. Tratase de um ritual que inocenta, purifica, livra de faltas, liberta e salva o confessor.

Ressaltamos que, nesse ritual, a dominação não está em quem fala, mas com aquele que escuta e cala; não está com quem sabe e responde, mas com quem interroga, assim como a verdade produzirá efeito não naquele que ouve o discurso, mas naquele de quem ele é extorquido. Dessa forma, Gulliver, em suas relações de confissão ao médico, ao padre e ao psicanalista, é sempre o dominado, aquele que fala, que sabe e responde sobre o seu delito. Seus pais não desistiram de encontrar a cura para o problema e o levaram ao psicanalista, Dr. Gatan que, após vários anos de análise, deu uma explicação que não resolveu o problema, pois o gato continuou do mesmo jeito.

$\mathrm{Na}$ escola, um professor que percebeu o sofrimento, "sempre sozinho, sem amigos, objeto da zombaria dos colegas" (ALVES, 2009, p. 12) - pelo diferente vive sob o crivo do sentimento de culpa e de inferioridade, que é inscrito em sua consciência individual - estabelece um diálogo com ele; utiliza-se da genética para lhe explicar sobre as diferenças e como o destino dos seres já está determinado pelo DNA. A cor dos olhos, do pelo, se seria gato ou gata e que ninguém é capaz de desfazer o que a natureza fez: 
- Por vezes, o disquete DNA não funciona da forma esperada. E, quando o bichinho nasce, nasce um pouquinho diferente. Alguns, chamados daltônicos, não vêem as cores do jeito como a maioria vê. Outros, chamados canhotos, funcionam melhor com a mão esquerda que com a direita. Eles têm de tocar violão ao contrário - e deu uma risada. - $\mathrm{Pa}-$ rece que esse é o caso com aqueles que têm uma dieta de amor diferente daquela reconhecida como padrão. O padrão é gato comer rato. Mas você gosta é de cenoura (ALVES, 2009, p. 14).

Existem muitas diferenças entre as pessoas, algumas são mais toleradas - talvez porque mais facilmente dissimuladas -, enquanto outras são, constantemente, alvo de apontamentos e rejeições. Gulliver rompeu com um padrão já estabelecido, seu hábito alimentar não corresponde ao dos outros membros de seu grupo. O discurso do professor contrapõese aos discursos médico e religioso; ele mostra que a diferença é possível:

- Os chamados heterossexuais amam o diferente: o corpo dos homens se comove ao ver um corpo de mulher; o corpo das mulheres se comove ao ver o corpo de um homem. Mas o corpo dos homossexuais, quem sabe se por obra do DNA, se comove ao ver um corpo igual ao seu (ALVES, 2009, p. 16).

O professor explicita que o desejo pode ser pelo oposto ou pelo igual; existem ambas 
as formas de desejo e elas são válidas. Tantas diferenças - de etnia, de gênero, de sexo e de cultura - existem em nossas salas de aula e há muito para dialogar, romper e avançar sobre elas. É o que ocorre com Gulliver, o qual ficou feliz por perceber que o seu professor o compreendia e não pretendia "consertá-lo" ou torná-lo igual aos outros: “'Meu Deus!” - ele gritou em silêncio. "Eu tenho um amigo! Eu tenho um amigo!"” (ALVES, 2009, p. 18). Sua única preocupação era não precisar ter vergonha, não queria ser igual aos outros, mas o que era: "um gato que gostava de cenouras!", queria que a sua identidade fosse aceita e respeitada, como muitos alunos - sujeitos desejam.

Como podemos perceber, os discursos religiosos e médicos oferecem possibilidades de cura, de salvação, como se a homoafetividade fosse uma patologia, um pecado, e a sua identidade e a subjetividade, consideradas segundo o padrão tido por legítimo. Nesse caso, o discurso pedagógico representa a possibilidade de compreensão, o ambiente escolar pode propiciar o diálogo das diferenças e o professor pode mediar esse processo que pretende romper com o preconceito e a indiferença em relação ao outro.

As convenções sociais determinam aquilo que é permitido e o que não é, a quem é permitido e em que contexto:

Só os períodos de crise social, cultural, ou pelo menos a irrupção de mobilizações politicas ou culturais, podem 
permitir um questionamento dessa ordem simbólica das representações e da linguagem cuja força principal é apresentar-se como se resultasse das evidências de uma ordem natural, imutável, e sobre a qual não se interroga ou sobre a qual falsamente se interroga para melhor reafirmá-la em seu arbitrário, apresentando-a como se tivesse sempre existido (ERIBON, 2008, p. 95-96).

Dentre os meios de representação está o currículo, que pode ser "um território contestado" (SILVA, 2009), na medida em que se torne capaz de desconstruir - e reconstruir - as representações de gênero, sexo, etnia e classe, dentre outras. A escola e o professor podem desempenhar um papel mais ativo e reflexivo em relação às relações de poder que o currículo estabelece. A leitura da narrativa infantil que analisamos é uma maneira de instaurar, nas salas de aula, o discurso, o conhecimento e o reconhecimento da diferença e da diversidade sexual, de oferecer voz a outras identidades. Então, por que não dar lugar ao livro O gato que gostava de cenoura em nossas bibliotecas? Por que não possibilitar, aos nossos alunos e alunas, o processo efetivo de humanização por meio da literatura? Por que não trabalhar com a leitura de textos que possibilitem uma efetiva e profícua discussão acerca das diferenças identitárias, constitutivas de nossas subjetividades? 


\section{Considerações finais}

Como procuramos demonstrar, o texto literário permite ao leitor o contato com a alteridade e, por conseguinte, com os valores sociais, culturais e históricos de uma sociedade que podem ser questionados ou não na tessitura do texto. Abordar determinadas temáticas, como, por exemplo, a diversidade sexual e de gênero, pode ajudar a desconstruir certos preconceitos arraigados em vários discursos de nossa sociedade balizada por uma matriz heterossexual, que inclui as identidades de gênero e sexuais que não se encaixam nas normas preestabelecidas.

A representação que o texto literário faz do outro pode auxiliar na desconstrução ou perpetuação do preconceito e das definições já enraizadas na sociedade. A narrativa infanto-juvenil que analisamos, por exemplo, permite-nos questionar padrões vigentes de modelos fixos de identidade, abrindo espaço para que o leitor, de forma crítica, perceba as ideologias e o envolvimento do social, do histórico e do cultural na elaboração do sentido e dos valores criados e transmitidos pelos personagens do texto.

Para que o leitor se posicione criticamente diante do que lê, não basta a simples leitura/ decodificação das palavras, é necessário que ele se aproprie da leitura e faça dela instrumento de (trans)formação. Assim, poderemos falar em uma efetiva formação de leitor crítico que, para ser efetivada, a nosso ver, requer a participação do professor como mediador de questões ainda 
consideradas dificeis de serem abordadas, mesmo constando em documentos oficiais, como os Parâmetros Curriculares Nacionais (PCN).

Se os PCN tratam da temática da diversidade sexual como tema transversal, se o texto literário permite uma abordagem interdisciplinar, acreditamos que é possivel, sim, a formação do leitor crítico para a diversidade, desde que a ele sejam dados os meios de dialogar com o texto literário e com esse outro representado no discurso literário. No entanto, as obras que tratam dessa temática não têm chegado à escola e às salas de aula, de modo que não têm sido trabalhadas nas escolas, ou por falta de preparo dos docentes, ou porque essas questões são vistas com "maus olhos" e, portanto, como desnecessárias à formação dos alunos.

Quando o professor discute com seus alunos uma narrativa literária que aborda questões não somente heterossexuais, abre espaço para a diversidade, para o diálogo com outras identidades, permitindo que os sujeitos leitores conheçam, questionem e reflitam a respeito do outro. Os discursos constituídos historicamente subsidiam a negação de determinadas identidades. É claro que não podemos negar, como pontuam os PCN para o Ensino Fundamental, que cada sociedade possui regras que regem o comportamento sexual, mas isso não deve significar a supervalorização de uma identidade em detrimento de outras, uma vez que vivemos em uma sociedade plural, e apontar uma ou outra identidade como "verdadeira" e "correta" faz com que diversas identidades sejam excluídas e reprimidas. 
Por meio do texto literário, é possível que se trabalhe com as crianças as temáticas apresentadas pelos PCN, dentre elas, a orientação sexual. A leitura do texto literário permite que o leitor desvele regras impostas por meio de discursos já arraigados na sociedade. O texto literário possibilita a formação de um leitor, capaz de questionar, compartilhar e experienciar a identidade do outro representado no texto. Por isso, a literatura infantil e juvenil, que se abre a revelar o outro, em suas diferentes identidades, possibilita, às crianças e aos jovens, perceber e respeitar aqueles que são diferentes.

Portanto, acreditamos que se trata de uma temática merecedora do devido respaldo dos professores em sala de aula, uma vez que eles são os mediadores, na maioria das vezes, entre o texto e o leitor, cabendo-lhes, desse modo, intermediar as reflexões e suscitar questionamentos que provoquem nos nossos jovens alunos, leitores em processo de formação, uma ruptura com alguns dos paradigmas tradicionais de nossa sociedade, como, por exemplo, a matriz heterossexual. A literatura, como forma de conhecimento, é um meio de se adquirir "noções, emoções, sugestões, inculcamentos" (CANDIDO, 2004 , p. 179), também um veículo para contestar "verdades" e discursos proferidos por quem detém o poder. Mesmo enfatizada como capaz de humanizar, não deveriamos considerar apenas o seu conteúdo e os valores éticos, pois age de diferentes modos na vida do ser humano, possibilitando-lhe uma maior compreensão do outro e do próprio meio social, cultural e histórico. 


\section{REFERÊNCIAS}

ALVES, Rubem. 0 gato que gostava de cenoura. 3. ed. São Paulo: Loyola, 2009.

BRASIL. Parâmetros Curriculares Nacionais: apresentação dos temas transversais. Secretaria de Educação Fundamental. Brasília, DF: MEC: SEF, 1997.

Parâmetros Curriculares Nacionais: orientação sexual. Secretaria de Educação Fundamental. Brasilia, DF: MEC: SEF, 1997.

CANDIDO, Antonio. O direito à literatura. In: . Vários escritos. São Paulo: Duas Cidades, 2004.

ERIBON, Didier. Um mundo de injúrias. In: Reflexões sobre a questão gay. Tradução de Procópio Abreu. Rio de Janeiro: Companhia de Freud, 2008.

FOUCAULT, Michel. História da sexualidade I: a vontade de saber. Tradução de Maria Thereza da Costa Albuquerque; J. Guilhon Albuquerque. Rio de Janeiro: Graal, 1988.

SILVA, Tomaz Tadeu da. Currículo e identidade social: territórios contestados. In: SILVA, Tomaz Tadeu da (Org.). Alienigenas na sala de aula: uma introdução aos estudos culturais em educação. Rio de Janeiro: Vozes, 2009. 
WOODWARD, Kathryn. Identidade e diferença: uma introdução teórica e conceitual. In: SILVA, Tomaz Tadeu da (Org.). Identidade e diferença: a perspectiva dos estudos culturais. Rio de Janeiro: Vozes, 2000. 